\title{
1 The role of power in the social studies of economics ${ }^{1}$
}

\author{
An introduction
}

\author{
Jens Maesse, Stephan Pühringer, Thierry Rossier \\ and Pierre Benz
}

\section{Economics and power}

The volume starts from the idea that economics as academic discipline and profession has enhanced influence and power during recent decades in many countries and in several social spheres. The forms of power, domination and authority that open up different channels of influence for economics are complex and diverse. But economics is not only a source of power, it is also product of power and domination through discourses, fields, networks and other means and tools. These discourses, fields and networks are controlled by different governmentalities and rules and they span different sectors of society. Thus, the study of economists, economics and economic expert discourse cannot be restricted to academia, as it involves a variety of domains of investigation (Maesse, 2015).

Accordingly, economists occupy positions at the top of institutional hierarchies in different sectors, such as banks and large firms, the state and the media, as well as within academia. They serve as consultants and advisors in several policy fields, ranging from fiscal to health and social security policy. Economists are appointed to the boards of big corporations, as governance experts, senior civil servants and central bankers. Economists are also members of consulting teams for newspapers and other media, regularly publish op-eds and leads, while acting as economic experts and translating their symbolic capital into policy by coining core "economic imaginaries" (Jessop, 2010). Actually, leading newspapers in the German-speaking area have started to establish their own economists' rankings based on their impact in several social spheres. Additionally, economists have become a dominant professional group, compared to traditional professions and other social science disciplines. At the international level, economists work in various influential organisations, such as the International Monetary Fund (IMF), the World Bank, the World Trade Organisation (WTO) and the European Central Bank (ECB) (Dezalay \& Garth, 1998).

Furthermore, economists cannot act within society without a strong base in academia and science. Accordingly, economists constitute one of the most advanced examples of an international scientific field, resulting from a long process of standardisation of practices, careers and curricula, as well as the adoption 
of external technical tools from mathematics and physics (Fourcade, 2006). Yet, economists do not form a homogeneous group, and their power is unequally distributed amongst members of the group. Strong hierarchies, compared to other academic disciplines and professions, characterise economics. There are only a few expressions for alternative approaches compared to the dominant orthodoxy in the field. This hierarchy, combined with a strong insularity in the field, helps to define a sentiment of self-confidence and superiority among group members (Fourcade et al., 2015). Economists face strong imbalances in the distribution of related capitals, and this stratification of the profession has implications for some features of their profiles. Economists are clearly underfeminised, and it can be hypothesised that, for the most part, they come from high social backgrounds. Women, individuals with a working-class background or with a particularly local profile are more or less excluded from resources in terms of chairs, research funds, grants and editorial board positions (Bayer \& Rouse, 2016). Nonetheless, such individuals are sometimes able to offer real challenges to dominant actors in the field.

To sum up, several channels exist through which economists influence public policy issues; aside from analysing the traditional role of economic experts as policy advisors, there is also a strand of research focusing on the political power of economic ideas, as well as more recent literature on the performativity of economic models and the role of economists as "public intellectuals" (i.e. economists who are engaged and highly visible in political and public debates) (Mata \& Medema, 2013). Consequently, aside from direct channels through which economic knowledge enters the political arena, there are also several indirect channels of impact that are mediated by intermediaries such as think tanks or media outlets (Hirschman \& Berman, 2014; Plehwe et al., 2018). These institutions play a crucial role in the transmission of economic ideas.

Our volume reflects on these complex interrelationships between science and society, where economic experts act and have an impact on several levels. In this way, we present 13 contributions from four different methodological and theoretical domains. Each chapter takes a particular view on the multiple dimensions of power, action and impact. To sum up, this volume offers complex insights into the forms of power in economics and provides a broad overview of recent developments in the evolving field of social studies of economics (henceforth SSE).

\section{Power as a complex phenomenon}

SSE developed as a field for the analysis on the role of economists in society. The groundbreaking works of Coats, Hall, Mirowski, Morgan, Fourcade and Lebaron opened up a research field that is hardly manageable today (Coats, 1993; Fourcade, 2009; Hall, 1989; Lebaron, 2001; Mirowski, 1991; Morgan, 1990). Especially in recent decades, a huge array of young researchers started the endeavour to form a research field out of the canonical classics (SchmidtWellenburg \& Lebaron, 2018a; Maesse et al., 2017; Mata \& Medema, 2013; 
Montecinos \& Markoff, 2009; Hirschman \& Popp Berman, 2014; Aistleitner et al., 2018). This work has developed in many national and disciplinary contexts, and it has shown how questions on the interrelation of power, discourse and knowledge have become important in this field. The contributions of this volume analyse the complex and widespread channels of influence as well as the mutual roles of economic experts in and on society from different disciplinary approaches and national contexts. It provides an overview of the diversity of perspectives and paradigms. Four different analytical views on the role of power and economics will be taken: first, the role of economic expert discourses as power devices for the formation of influential expertise; second, the logics and modalities of governmentality that produce power/knowledge apparatuses between science and society; third, economists as they are involved in networks between academia, politics and the media; and fourth, economics considered as a social field, including questions of legitimacy and unequal relations between economists based on the accumulation of various capitals.

In order to study economic expert knowledge, discourse analytical approaches became popular within SSE. Economic expert knowledge is mainly analysed from three perspectives. First, the production of economics knowledge is studied by economic historians and cultural sociologists (Coats, 1993; Morgan, 1990). In particular, different paradigms, hegemonic theories and marginalised forms of knowledge were analysed in order to understand how power relations influence the production of economic truths (Dobusch \& Kapeller, 2009; Mirowski, 1991; Ötsch et al., 2017). In addition to this production-oriented research, the influence of economic expert knowledge on society became a major research field. Here, performativity studies have shown how economics as discursive tool impacts on the formation of markets and firms (Callon, 1998; MacKenzie et al., 2007; and critically Sparsam \& Pahl in this volume). Other studies have taken into account the formation of legitimacy, argumentation strategies and speaker positions via economic expert discourses (Fitzgerald \& O’Rourke, 2015; Maesse, 2015; Pühringer \& Griesser, 2020; and Bäuerle in this volume). Both approaches - production and impact orientation - mostly interact by focusing on diverse forms of the circulation of knowledge and the various types of interpretative adoption by experts, professionals, politicians and the media (Maesse, 2017, and in this volume). Here, economic expertise is seen as a tool for exercising power through hegemonic discourses in different social contexts, such as politics, the business world and the media (SchmidtWellenburg, 2018). Finally, a third form of discourse analytical perspective considers diverse forms of informal knowledge (Maesse, 2018; Rossier \& Bühlmann, 2018). This knowledge accounts for informal social rules in organisations, tacit knowledge in professional fields, institutional norms and values of politics and academia, as well as the social networks that control access to certain institutions and regulate official and unofficial membership categories.

Closely related to discourse approaches, governmentality studies analyse economics and economic expertise as a form of "soft power". Starting form Foucault's work on governmentality and "neoliberalisation" studies (Dean, 1999; 
Foucault, 2008; Miller, 2001), economics is seen as a governance tool for the creation of various forms of subjectivities. As Psyllakou shows in this volume, TV shows and certain forms of economic language can be analysed as mechanisms for producing and controlling the emotions of people. In addition to that, Nicoletta analyses in this volume how an economic governance apparatus in Italy emerged. Other studies have shown how neoliberal ideologies and economic theories interact in order to create certain political perceptions and interpretative frames (Zuidhof, 2012; and Gürkan in this volume). In addition, many studies have analysed how neoliberalism recruits economic experts and ideas in order to implement certain political programmes serving the interests of the ruling classes. In this volume, Bjerke shows how this works in the case of market theory. However, various other study areas have analysed the governmentality of neoliberalism, for example financialisation studies (Erturk et al., 2008). The main contribution of governmentality approaches to SSE can be seen in their ability to bring together critical views of knowledge use, connecting them to new approaches to power and domination and offering a new field for discourse analytical methods. Additionally, network and field approaches to economics are closely connected to the role of power/knowledge apparatuses considered by governmentality studies.

Another trend within SSE is the analysis of network structures in economics, either to investigate the transmission of economic knowledge into politics or to unveil social power structures inside academic economics. In the first case, a social network perspective enables highlighting the connections of economists to powerful elites and their involvement in policymaking processes, as well as the role of networks in spreading economic ideas in general. In this respect, recent approaches in SSE are related to critical policy studies (Mirowski \& Plehwe, 2009) and the evolving field of think-tank network research (SalasPorras \& Murray, 2017). Thus, scholars are explicitly focusing on a sample of politically engaged economists and investigating personal (e.g. co-authorships, collaborations) and institutional (e.g. memberships, positions) networks between economic experts and advice bodies, as well as economic think tanks or initiatives (Grimm et al., 2018; Flickenschild \& Afonso, 2019; Pühringer, 2020; and Theine and Pühringer \& Beyer, in this volume). In this way, they are able to show the formative role of such personal-institutional networks in the process of the transmission of economic knowledge into policymaking (Helgadóttir, 2016; Plehwe et al., 2018; and Gautier Morin in this volume). In the second case, researchers are typically interested in hierarchies, stratification logics, path dependencies and network effects inside academia, and thus they often combine social network analysis (SNA) with bibliometric and/or biographical analyses (Beyer \& Pühringer, 2019; Coman, 2019). While SNA as applied in SSE is rooted in early economic sociology (e.g. Granovetter, 1983), current approaches make use of the availability of huge databases and advanced analytical tools. In this vein, recent studies have investigated "citation cartels" between economic journals (Anauati et al., 2018) and authors (Önder \& Terviö, 2015). On a more individual level, scholars also show that established social networks between economists and actors outside academic economics play a crucial role 
in shaping the prospects for successful academic careers (Rossier, 2020; and Rossier \& Benz in this volume). This volume contributes to the debate on the public and political impact of economics by providing novel empirical analyses of social networks of economists both inside and outside academia.

A final approach conceptualises economics as a field (Bourdieu, 2005). Within this more or less autonomous social space, economists compete for the definition of both the field's boundaries and what (good) economics is (Lebaron, 2000). The distribution of capital, defined as a group of powerful resources involved in systemic processes allowing their garnering by those who possess them (Savage et al., 2005), and economists' individual dispositions shape their position in the field's structure and their scientific and political position-takings (Lebaron, 2001). This approach focuses on two particularities characterising this field. First, economics as a scientific discipline is subject to transnational processes of scientific recognition with, at the top of the hierarchy, a few US departments and scientific journals, as well as the Nobel and the "Nobel" prize, which shape academic careers and citations (Korom, 2020, and in this volume). The import of resources acquired in those departments provides economists with advantageous positions in their home countries (Dezalay \& Garth, 2002; Gautier Morin \& Rossier, 2021). Second, economics occupies a particularly central place within the field of power, i.e. the field of dominant individuals from all other fields (Bourdieu, 1996). Neoclassical economic theory contributes to spreading an "economic belief" that consolidates the production of a "dominant ideology", which reflects the interests of a capitalist class and legitimises the social order (Gautier Morin in this volume). Economists are not just a social group with increasing importance in the academic context but also most certainly the producers of some of the most important tools and perceptions to govern today's societies (Schmidt-Wellenburg \& Lebaron, 2018b: 20). Consequently, they have a strong influence on policymaking and occupy positions among the public administration and private sector elites (Rossier et al., 2017; Klüger, 2018, and in this volume), whereas their internal debates often take place well beyond the field's borders, such as in the political arena (SchmidtWellenburg, 2018) and the media (Gautier Morin, 2019). More generally, when studying economics as part of a field-analytical strategy (Bourdieu \& Wacquant, 1992), three interrelated dimensions are highlighted. First, economics is considered in relation to the field of power by stressing where economists are situated within this powerful space. Second, the objective structure of relations through the distribution of specific capital in economics is highlighted. This also includes a focus on economists' biographical and network-related resources. Third, processes related to economists' field-specific habitus, defined as a set of embodied dispositions that organise their ways of acting, thinking, feeling and perceiving (Lenger, 2018), are uncovered. Studying economists' habitus allows us to understand the relations between their position in the field and their theoretical, methodological and political position-takings. The chapters in this volume contribute, each in its own way, to the study of economics at those three levels, by focusing on original cases through the lens of different quantitative and qualitative descriptive methodologies. 


\section{Fields of investigation}

This book, through its four analytical dimensions, addresses the changes that economics underwent during recent decades, gaining influence and power in many countries and in several social contexts. The chapters of this book will help us to understand economics as it is involved in many power games. The relationship of power and knowledge production is complex and accounts for the special role of economics in current societies. This volume collects 13 contributions from different (qualitative and quantitative) methodological and theoretical fields. Each contribution takes a particular view on the multiple dimensions of power, knowledge and influence. The authors discuss various aspects related to economics as an academic discipline and profession from four main perspectives in SSE: discourse analysis, governmentality studies, network studies and field theory. Via these approaches we can understand several forms of power related to the profession, as well as various challenges that need to be analysed from a critical and interdisciplinary perspective. In order to represent different disciplines, the authors have backgrounds in sociology, history, political science, linguistics and economics. These studies cover a large historical period, mainly the second part of the 20th century, and focus on a variety of national cases (including the USA, Germany, Italy, Switzerland, Greece, Mexico, Brazil) and international institutions, such as the IMF. In addition, various qualitative and quantitative methodologies and research strategies are applied, such as interviews, content and documentary analyses, prosopography, historical and archival research, discourse analysis, text statistics, social network analysis, sequence analysis and geometric data analysis (multiple correspondence analysis). The main idea of the volume is to bring together different but interrelated analytical strategies in relation to a highly important phenomenon that is central to the formation of current globalised societies. The volume contributes to the formation and consolidation of SSE as a growing research field. It will help to make visible the diversity of research approaches that make this field attractive to scholars in political economy, economic sociology and beyond. Due to its methodologically and theoretically interdisciplinary perspective, this volume will serve furthermore as a reference point for future research avenues in the field of SSE. The book is organised into four sections. The first section deals with the relationship of discourse and power in economic expert knowledge production; the contributions of section two analyse practices of economic governmentality; section three will take into account networks of economic experts; and the final section analyses economics from a field angle.

\section{Contributions to the social studies of economics}

The chapters of the first part, Economic Knowledge and Discursive Power, analyse economic discourses from different methodological viewpoints. Jens Maesse's chapter, "Performative, imaginary and symbolic power: how economic expert 
discourses influence society", stresses different forms of discursive power. According to him, when economic experts start to speak, they do not simply enter into equal and non-coercive communications with other actors in the political economy. On the contrary, economic expert discourses have various impacts on the formation of societies. These discourses produce different forms of power and subjectivation. Starting from a Foucauldian approach to power and discourse, his contribution shows how economic expert discourses operate as power devices. Three different forms of discursive power are presented and illustrated, taking examples from the Brexit discourse and previous research on economics departments. First, he shows how the "performative power" of economic expert discourses contributes to the construction of institutional positions in European politico-economic relations. In a second step, he demonstrates how the polyphonic structure of controversies over the economic rationality of Brexit produces speaker positions. These positions are analysed as "imaginary power" that contributes to the formation of social identities. In a third step, his contribution analyses the role and logic of academic excellence discourses as "symbolic power" for the formation of superiority myths of expert positions in public discourses. By sketching out the complex field of discourse and power in economic expert communication, this contribution helps to understand the various forms and mechanisms of power that are at work beyond hierarchies, interests and domination practices.

The chapter by Jan Sparsam and Hanno Pahl, "Macroeconomics and monetary policy as autonomous domains of knowledge and power: rational expectations, monetarism and the Federal Reserve", investigates central bank policies. They start from the idea that academic macroeconomics and monetary policy in central banks share a strong connection. However, the practical needs and epistemic cultures in both domains differ significantly, so there is no straightforward dissemination of macroeconomic ideas into practical monetary policymaking. Instead, academic macroeconomics and central banks have to be understood as autonomous domains of knowledge and power. They refer to two case studies concerning the Federal Reserve, the central bank of the USA, to reveal the context conditions of action in the respective domains that are responsible for the transition of knowledge between them. The first case shows the imminent failure of the project to popularise rational expectations in the Federal Open Market Committee. Indeed, rational expectations revolutionised academic macroeconomics but not monetary policymaking. The second case shows how pragmatic needs when facing a crisis led the Federal Open Market Committee to selectively adopt monetarist ideas. Both case studies draw on verbatim transcripts of meetings of the Federal Open Market Committee.

Lukas Bäuerle, in "The power of economics textbooks: shaping meaning and identity", shows how textbook knowledge influences students of economics. By conducting a discourse analysis (SKAD) in the field of academic economics textbooks, this chapter aims to reconstruct the frames and identity options offered to undergraduate students relating to the questions of "Why study economics?" and "Who do I become by studying economics?" 
The analysis shows three major frames and respective identity offerings, all of which are contextualised theoretically. While a first frame promises that students will learn "eternal truths", thereby becoming "specialised knowers", a second frame encourages students to capitalise on their education by becoming self-entrepreneurs. A third frame combines the "Why?" of economic education directly with identity options by granting students insights into their "real" and "true" inner state. Taken together, economics textbooks appear as a total structure of actions brought to bear upon possible action, thus being a genuine example of Foucauldian power structures.

The second part, Economic Governmentalities, analyses economics as a governance tool. Ceyhun Gürkan, in "The constitution of neoliberal governmentality from early neoclassical economics to public choice theory", shows how neoliberalism emerged and changed over time. Drawing on Foucault, this chapter demonstrates the particular role of early neoclassical economics between the 1870 s and the 1920s, and public choice theory throughout the second half of the 20th century in the constitution of neoliberal governmentality. Foucault examines how classical political economy and neoliberal economics developed two versions of liberalism. However, he mentions early neoclassical economics in a scattered and sparse manner and does not touch upon public choice theory as part of the developing neoliberal governmentality at all. The main argument is that an overall historical understanding of neoliberal governmentality can be achieved by pondering the radical modifications of classical liberalism by early neoclassical economics moving towards neoliberal governmentality and, by extension, the subsequent comprehensive modifications carried out based on public choice theory. The methodology of the chapter relies on Foucault's analytics of power/government, the nominalist method and the genealogical history of ideas. It concludes that governmentality-based analysis of early neoclassical economics and public choice theory concerning their related theoretical and discursive tools, and political reason, prove to complement the new lines of Foucauldian critique of neoliberal governmentality.

Flemming Bjerke, in "Competitive power: elements of Foucauldian economics", reflects on Foucauldian market theory. Economics generally excludes empirical analyses of how the soft power of marketing is exercised. Applying Foucault's concepts of power offers a fruitful way of analysing marketing as an exercise of power, which implies that competition must be defined in terms of power. In Foucauldian economics, business economists not only observe markets but also have to exercise power and must therefore acquire the rationalising skills of professional power technologies. Competitive firms participate in a competition dispositive which constitutes general principles for integrating a competing firm within its environment. Competition does not only spur differentiation and growth, it also expands throughout society, tending to become the dominant way of exercising power. This implies that the economy is basically irreversible and usually not in equilibrium.

In "Feelings in crisis: the emotional and affective dimension of neoliberal economics in Greek crisis prone society", Elena Psyllakou investigates the 
role of emotions in economic discourses. According to her, what is referred to as "neoliberalism" is often understood as a regime of emotional governance restricting, controlling and excluding emotions. Building a comparative framework between fragments of early "neoliberal" philosophical thought and critical work on current manifestations of neoliberal governance, the aim of this chapter is to track how interdiscursivities between neoliberal economics and socio-political practices largely rely on emotional and affective articulations that cannot be theorised in a singular way. She focuses on the neoliberal project pursued in Greece, as partly reflected in Greek bank advertising during the crucial years of imposed austerity policies and resistance (2009-2016). Employing critical discourse analysis, her chapter problematises the "negative" hypothesis of emotional exclusion and critically approaches the emotional and affective strategies of a specific form of culturally neoliberal governmentality.

In his chapter entitled "Laboratories for economic expertise: lay perspectives on Italian disciplinary economics", Gerardo Costabile Nicoletta analyses three Italian historical experiences as laboratories of transnational networks of disciplinary economics and deals with the contingent and (con)textual character of the power of economics, starting from its relationship with the object of its discursive and practical interventions: laypeople. This fundamental relational dimension, the source of economists' power in the global political economy, is often underestimated by current social studies on economics, which implicitly assume a self-referential and autopoietic foundation of this power. Conversely, combining discursive political economy, sociologies of expertise and transnational historical sociology, his contribution analyses economic expertise as a complex network of practices, discourses and institutions constantly and strategically deployed to deal with socio-political contingencies. His lay perspective on the Italian experience proposes a socio-historical understanding of economists' apparently neutral set of governmental practices. In this light, measurements, operative tools and conceptual apparatuses can be interpreted as practical and discursive interventions shaping strategically specific epistemic regimes and relational fields aiming to separate organisational and material issues from popular control and marginalising possible alternatives to get population and territories in line with socio-technical divisions of labour.

The third part, Economists in Networks, focuses on the circulation and network ties of economists and economic ideas in academia, national and transnational politics, the media and public discourses. In "Who are these economists Germany listens to? The social structure of influential German economists", Stephan Pühringer and Karl Beyer build on recent work on the political and societal impact of economics and distinct economists, respectively, to examine individual, research and institutional characteristics, as well as existing professional networks of what are considered to be "influential economists" in Germany. Through biographical research and the application of social network analysis, they show that most influential economists are involved in co-authorship and/or institutional networks, and that there are substantial connections to different levels of public governance. They find a tremendous 
gender bias within the sample as well as some hints for internationalisation and the division of labour. Their analysis, moreover, indicates a much less hierarchical structure of the German-speaking economics profession when compared to the US. However, they find that while a striking majority of media and policy advice economists have connections to (inter)national public governance bodies, only a minority of research economists have such connections. Furthermore, the ordoliberal bias, which is a crucial feature of the German economics profession, is mainly restricted to media and policy advice economists. Finally, their analysis indicates the central role of (also partly geographically organised) research hubs among influential research economists.

In her chapter "Global production and circulation of dominant ideologies: Mexico from the default debt crisis to the Brady Plan (1982-1989)", Johanna Gautier Morin provides a renewed understanding of multilateral financial cooperation and the role of economists in the ideological convergence that accompanied capital flows in the case of the Mexican default on external debt. According to this chapter, the core-periphery model has long distorted the study of multilateral cooperation. The 1970s-1980s marked a turning point in the transnational experimentation of economic policies, converting the Latin American sub-continent into a social laboratory. Most studies on the topic focused on the IMF's and the World Bank's methods, hegemonic business practices, or the international circulation of economic ideas. Few have explored the agency of the countries involved in such unbalanced situations and the central role they have played in the global financial revolution that has transformed markets over these two decades. In this chapter, she explores how negotiations were conducted in a context of financial dependency and transposes the theoretical proposals of Bourdieu and Boltanski on the production of the dominant ideology to the Mexican default on external debt in 1982. She analyses the crisis as a proxy for revealing the structural mechanisms of Mexican economic policies. This allows her to examine the global circulation of economic ideas at the heart of the negotiations between the Mexican government, the IMF, the US Treasury and investment banks involved in managing the crisis. The failures of the structural adjustment programmes tested the technocratic theories applied to the Mexican case and revealed the function of economic policy rhetoric in supporting the circulation of capital flows in the changing world of the 1980 s.

In the final chapter of this part, entitled "Economists in public discourses: the case of wealth and inheritance taxation in the German press", Hendrik Theine investigates the role of economists in public discourses. Conceptually, he draws on the recent "cultural turns" in regulation theory and post-Marxist thinking, and in particular on the work of Bob Jessop and Antonio Gramsci in their discussion of intellectuals and their role in society. Empirically, the role of economists is investigated by drawing on the example of wealth and inheritance taxation in the German press at the beginning of the 21st century. The empirical analysis shows that well-known economists frequently occur in newspaper coverage. Furthermore, the stark dominance of economists 
associated with mainstream economics and ordoliberalism over post-Keynesian and other heterodox economists is revealed. Given the role of economists as organic intellectuals in the political economy, this points to a continuing legitimation and normalisation of the structural power of the capital class to assert their interests regarding low wealth and inheritance taxation.

The fourth part, Economics as a Scientific Field, centres on the social structure of the discipline, according to the distribution of its specific and external capitals among economists, along biographical and network dimensions. The chapter by Philipp Korom, "Are there institutionalized pathways to the Nobel Prize in economics?", proposes an empirical study of scientific careers in the field of economics. It focuses on the Nobel Prize, the single ne plus ultra award in economics, which has been awarded for half a century. Indeed, the preconditions for receiving the highest consecration of achievement are understudied. While the consideration of a few single cases, such as the life and work of Herbert Simon or John Nash, might suggest that the most successful scholars in economics are a rather varied collection of individuals, a prosopographical study of 81 Laureates reveals institutionalised pathways to the prize: The academic careers of Laureates nearly always lead to professorships in the top five departments of the discipline. Visiting professorships at the "big five" are another common characteristic. Similarly, publications of Laureates are concentrated in the top five journals. The academic profile of Laureates in economics mirrors the unitary macrostructure of the discipline, which is dominated by an elite subset of American universities, rather than by departments across the world.

Thierry Rossier and Pierre Benz, in "Forms of social capital in economics: the importance of heteronomous networks in the Swiss field of economists (1980-2000)", focus on the structure and evolution of social capital in the Swiss field of economists. They start from the fact that economists often argue that economics is a "pure" and "autonomous" discipline. In contrast, the relatively dense institutional and interpersonal networks owned by economists show how the discipline stands at the edge of several social fields, and thus can be particularly heteronomous. These networks provide a certain volume and form of social capital which strengthens the discipline, but they highlight its important porousness toward extra-academic powers. Very few studies have focused on the importance of social capital in fields and, according to Rossier and Benz, even less have systematically investigated the role of intra-disciplinary and extra-disciplinary social capital in economics. This chapter therefore aims to focus on the structure and evolution of social capital in the Swiss field of economists. It relies on an original prosopographical database of all economics professors at Swiss universities between 1980 and $2000(n=200)$. The authors exploit the data in two ways: First, through multiple correspondence analysis (MCA), they identify two structuring forces among economists. The main opposition is marked by the volume of extra-disciplinary social capital, and the volume of intra-disciplinarity capital only comes in second place. Second, they show, through class-specific MCA, that, despite the fact that intra-disciplinary social capital has gained in importance in the recent period, extra-disciplinary 


\section{Jens Maesse et al.}

social capital remains the prime structuring logic across time. Despite the particularly strong cohesion and autonomy that characterise the discipline, this chapter points to the importance of heteronomous networks, which attest that economics is and remains much less autonomous than economists would argue.

Finally, in "Paths of international circulation: how do economists and economic knowledge flow?", Elisa Klüger investigates international circulation as a source of legitimacy and power for economists that distinguishes, technically and socially, those who have access to foreign institutions and cosmopolitan assets. These resources are particularly prized in peripheral nations, where connections with central areas are valuable capital for those aiming for prominent political/administrative positions. Moreover, going abroad has effects on the type of economic ideas diffused through peripheral areas. The questions addressed in this chapter are How do economists and economic ideas flow? and How do dissimilar ideas spread and (re)shape a structured space of economists? Klüger focuses on the Brazilian case, in which the space of economists is deeply amalgamated with external influences. After describing how international ties helped to shape the Brazilian space of economists, social network analysis is used to depict a polarised social space and reveal patterns of connections with foreign agents and institutions. The network illustrates that circulations towards the US, Europe and Latin America lie in dissimilar areas of the Brazilian space of economists, and that different streams of economic knowledge spread from each of these sources.

To conclude, this book addresses a large array of subjects and offers a variety of disciplinary perspectives. It contributes to study economics as an academic discipline and a professional occupation by extending conceptual and methodological frameworks for better understanding how economics, economic expert discourse and economists influence societies. Finally, this book provides important empirical data by focusing on discourses and networks in economics and considering economics as a governance tool and field. It therefore aims to consolidate SSE as a comprehensive and diversified research agenda rooted in various disciplines of the social sciences and humanities.

\section{Note}

1 Stephan Pühringer gratefully acknowledges funding by the Austrian Science Fund FWF (grant number ZK60-G27).

\section{References}

Aistleitner, M., Kapeller, J., \& Steinerberger, S. (2018). The Power of Scientometrics and the Development of Economics. Journal of Economic Issues, 52(3), 816-834.

Anauati, M. V., Gálvez, R., \& Galiani, S. (2018). Differences in Citation Patterns across Journal Tiers in Economics. NBER Working Paper Series. (25101).

Bayer, A., \& Rouse, C. E. (2016). Diversity in the Economics Profession: A New Attack on an Old Problem. Journal of Economic Perspectives, 30(4), 221-242. 
Beyer, K., \& Pühringer, S. (2019). Divided We Stand? Professional Consensus and Political Conflict in Academic Economics. ICAE Working Paper Series (94).

Bourdieu, P. (1996). The State Nobility: Elite Schools in the Field of Power. Cambridge: Polity Press; Oxford: Blackwell Publishers Ltd.

Bourdieu, P. (2005). The Social Structures of the Economy. Cambridge: Polity Press.

Bourdieu, P., \& Wacquant, L. J. D. (1992). An Invitation to Reflexive Sociology. Chicago: University of Chicago Press.

Callon, M. (Ed.). (1998). The Laws of the Markets. Oxford: Blackwell.

Coats, A. B. (1993). The Sociology and Professionalization of Economics: British and American Economic Essays (Vol. 2). Abingdon-on-Thames: Routledge.

Coman, R. (2019). Transnational Economists in the Eurozone Crisis: Professional Structures, Networks and Ideas. New Political Economy, 93(3), 1-14.

Dean, M. (1999). Governmentality: Power and Rule in Modern Society. Thousand Oaks, CA: Sage.

Dezalay, Y., \& Garth, B. (1998). Le "Washington Consensus". Actes de la Recherche en Sciences Sociales, 121(1), 3-22.

Dezalay, Y., \& Garth, B. (2002). The Internationalization of Palace Wars: Lawyers, Economists, and the Contest to Transform Latin American States. Chicago: Chicago University Press.

Dobusch, L., \& Kapeller, J. (2009). Why Is Economics Not an Evolutionary Science? New Answers to Veblen's Old Question. Journal of Economic Issues, 43(4), 867-898.

Erturk, I., Froud, J., Johal, A., Leaver, A., \& Williams, K. (Eds.). (2008). Financialization at Work: Key Texts and Commentary. Abingdon-on-Thames: Routledge.

Fitzgerald, J., \& O’Rourke, B. K. (2015). Performing Economics: How Economics Discourse Gets Enacted in Radio News Interviews. 10th international conference in interpretive policy analysis.

Flickenschild, M., \& Afonso, A. (2019). Networks of Economic Policy Expertise in Germany and the United States in the Wake of the Great Recession. Journal of European Public Policy, 26(9), 1292-1311.

Foucault, M. (2008). The Birth of Biopolitics. Lectures at the Collège de France, 1978-1979. London: Palgrave Macmillan.

Fourcade, M. (2006). The Construction of a Global Profession: The Transnationalization of Economics. American Journal of Sociology, 112(1), 145-194.

Fourcade, M. (2009). Economists and Societies: Discipline and profession in the United States, Britain, and France, 1890s to 1990s. Princeton: Princeton University Press.

Fourcade, M., Ollion, E., \& Algan, Y. (2015). The Superiority of Economists. Journal of Economic Perspectives, 29(1), 89-114.

Gautier Morin, J. (2019). The Keynesian-Monetarist Competition over Public Credibility. The Tocqueville Review, 40(2), 281-294.

Gautier Morin, J., \& Rossier, T. (2021). The Interaction of Elite Networks in the Pinochet Regime's Macroeconomic Policies. Global Networks, online first. DOI: 10.1111/glob.12300.

Granovetter, M. (1983). The Strength of Weak Ties: A Network Theory Revisited. Sociological Theory, 1, 201-233.

Grimm, C., Kapeller, J., \& Pühringer, S. (2018). Paradigms and Policies: The Current State of Economics in the German-speaking Countries. ICAE Working Paper Series (77).

Hall, P. A. (Ed.). (1989). The Political Power of Economic Ideas: Keynesianism Across Nations. Princeton: Princeton University Press. 
Helgadóttir, O. (2016). The Bocconi Boys Go to Brussels: Italian Economic Ideas, Professional Networks and European Austerity. Journal of European Public Policy, 23(3), 392-409.

Hirschman, D., \& Popp Berman, E. (2014). Do Economists Make Policies? On the Political Effects of Economics. Socio-Economic Review, 12(4), 779-811.

Jessop, B. (2010). Cultural Political Economy and Critical Policy Studies. Critical Policy Studies, 3(3-4), 336-356.

Klüger, E. (2018). Mapping the Inflections in the Policies of the Brazilian National Economic and Social Development Bank during the 1990s and 2000s within Social Spaces and Networks. Historical Social Research, 43(3), 274-302.

Korom, P. (2020). How Do Academic Elites March Through Departments? A Comparison of the Most Eminent Economists and Sociologists' Career Trajectories. Minerva, online first. DOI: 10.1007/s11024-020-09399-1.

Lebaron, F. (2000). La croyance économique. Les économistes entre science et politique. Paris: Editions du Seuil.

Lebaron, F. (2001). Economists and the Economic Order. The Field of Economists and the Field of Power in France. European Societies, 3(1), 91-110.

Lenger, A. (2018). Socialization in the Academic and Professional Field: Revealing the Homo Oeconomicus Academicus. Historical Social Research, 43(3), 39-62.

MacKenzie, D. A., Muniesa, F., \& Siu, L. (Eds.). (2007). Do Economists Make Markets? On the Performativity of Economics. Princeton: Princeton University Press.

Maesse, J. (2015). Economic Experts: A Discursive Political Economy of Economics. Journal of Multicultural Discourses, 10(3), 279-305.

Maesse, J. (2017). The Elitism Dispositif: Hierarchization, Discourses of Excellence and Organizational Change in European Economics. Higher Education, 73(6), 909-927.

Maesse, J. (2018). Opening the Black Box of the Elitism Dispositif: Graduate Schools in Economics. In R. Bloch, A. Mitterle, C. Paradeise, \& T. Peter. Universities and the Production of Elites: Discourses, Policies, and Strategies of Excellence and Stratification in Higher Education (pp. 53-79). London: Palgrave Macmillan.

Maesse, J., Pahl, H., \& Sparsam, J. (Eds.). (2017). Die Innenwelt der Ökonomie: Wissen, Macht und Performativität in der Wirtschaftswissenschaft. Berlin/Heidelberg: Springer.

Mata, T., \& Medema, S. (Eds.). (2013). The Economist as Public Intellectual. Durham: Duke University Press.

Miller, P. (2001). Governing by Numbers: Why Calculative Practices Matter. Social Research, 68(2), 379-396.

Mirowski, P. (1991). More Heat Than Light: Economics as Social Physics, Physics as Nature's Economics. Cambridge: Cambridge University Press.

Mirowski, P., \& Plehwe, D. (Eds.) (2009). The Road from Mont Pèlerin: The Making of the Neoliberal Thought Collective. Cambridge, MA: Harvard University Press.

Montecinos, V., \& Markoff, J. (2009). Economists in the Americas. Cheltenham: Edward Elgar. Morgan, M. S. (1990). The History of Econometric Ideas. Cambridge: Cambridge University Press.

Önder, A. S., \& Terviö, M. (2015). Is Economics a House Divided? Analysis of Citation Networks. Economic Inquiry, 53(3), 1491-1505.

Ötsch, W. O., Pühringer, S., \& Hirte, K. (2017). Netzwerke des Marktes: Ordoliberalismus als Politische Ökonomie. Berlin/Heidelberg: Springer.

Plehwe, D., Neujeffski, M., \& Krämer, W. (2018). Saving the Dangerous Idea: Austerity Think Tank Networks in the European Union. Policy and Society, 37(2), 188-205. 
Pühringer, S., \& Griesser, M. (2020). From the 'Planning Euphoria' to the 'Bitter Economic Truth': The Transmission of Economic Ideas into German Labour Market Policies in the 1960s and 2000s. Critical Discourse Studies, online first. DOI: 10.1080/17405904.2019.1681283.

Rossier, T. (2020). Accumulation and Conversion of Capitals in Professorial Careers. The Importance of Scientific Reputation, Network Relations, and Internationality in Economics and Business Studies. Higher Education, online first. DOI: 10.1007/s10734020-00508-3.

Rossier, T., \& Bühlmann, F. (2018). The Internationalisation of Economics and Business Studies: Import of Excellence, Cosmopolitan Capital or American Dominance? Historical Social Research, 43(3), 189-215.

Rossier, T., Bühlmann, F., \& Mach, A. (2017). The Rise of Professors of Economics and Business Studies in Switzerland: Between Scientific Reputation and Political Power. European Journal of Sociology, 58(2), 295-326.

Salas-Porras, A., \& Murray, G. (Eds.). (2017). Think Tanks and Global Politics: Key Spaces in the Structure of Power. London: Macmillan.

Savage, M., Warde, A., \& Devine, F. (2005). Capitals, Assets, and Resources: Some Critical Issues. British Journal of Sociology, 56(1), 31-47.

Schmidt-Wellenburg, C. (2018). Struggling Over Crisis. Discoursive Positionings and Academic Positions in the Field of German-Speaking Economists. Historical Social Research, 43(3), 147-188.

Schmidt-Wellenburg, C., \& Lebaron, F. (Eds.). (2018a). Economists, Politics, and Society. New Insights from Mapping Economic Practices Using Field-Analysis. Historical Social Research, Special Issue, 43(3).

Schmidt-Wellenburg, C., \& Lebaron, F. (2018b). There Is No Such Thing as "the Economy". Economic Phenomena Analysed from a Field-Theoretical Perspective. Historical Social Research, 43(3), 7-38.

Zuidhof, P. W. (2012). Imagining Markets: The Discursive Politics of Neoliberalism. Rotterdam: Erasmus University Rotterdam. 